\title{
PRACTICE AND PERSPECTIVES OF IMPLEMENTATION OF LAW STUDY COURSES IN FACULTIES OF LAW IN UNIVERSITIES OF APPLIED SCIENCES
}

\author{
Andrejs Vilks \\ Rīga Stradiņš University, Latvia \\ Aldona Kipāne \\ Rīga Stradiņš University, Latvia
}

\begin{abstract}
The dynamism of social processes, the continuous development of elements of the legal system, including innovations within the legal framework, the ongoing reform of law enforcement institutions and bodies, diversity of national and international legal practices, transformation of legal culture forms, including its deformations, define the need for developing of qualitative law study programmes (Bachelor, Master, PhD). Legal professionals need regularly to improve their legal knowledge and to ensure successive professional development. The qualitative implementation practice of study courses of law science and the prospects of their implementation are one of the key elements for the development of a democratic, legal and socially responsible state.

Research aim: to identify the current practice of implementation of law science curricula and of study courses by modelling their potential development trends according to perspective social-economic development of society.

Research methods: research of legal sources and literature, the Internet resources, modelling approach.
\end{abstract}

Keywords: legal education, study courses, curricula, law science.

\section{Introduction}

Social life is becoming more and more rapid and intense, and social, political, financial, economic, legal and other situations (environmental conditions) are becoming more diverse and controversial. The dynamic and contradictory development of the environment requires from the individuals involved in communicative processes to gain and have high level knowledge, skills, abilities and competences. Continuous promotion and development of the corresponding qualities are of particular importance. In this context, the importance of the education system and its successive, sustainable development is growing. The education system is very broad in scope and comprehensive. The authors of this article do not aim to delve into the entire spectrum of its overall 
development. Legal education is an important area of the development of society and the education system. The practical aspect of legal education is that special attention is paid to the development of legal skills in the study process, involving students in solving weddings, wider use of practical classes, organization of court games.

The dynamism of social processes, the continuous development of elements of the legal system, including innovations within the legal framework, the ongoing reform of law enforcement institutions and bodies, diversity of national and international legal practices, transformation of legal culture forms, including its deformations, define the need for developing of qualitative law study programmes. In addition, legal professionals need regularly to improve their legal knowledge and to ensure successive professional development. In every society, lawyers are expected to be able to respond quickly to changing conditions of life, which one can apply to all spheres of public life. The President of Latvia, Egils Levits has emphasized that lawyers are responsible for the legal system of Latvia. In addition, teaching staff of the faculty also strengthens Latvia as a legal state by performing academic work and educating young lawyers. The President reminded that the profession of a lawyer, unlike many others, demands personal loyalty to the state because the rights and the law are intrinsically linked to political ideas (Gailīte, 2019).

The qualification of a lawyer covers a very wide range of areas in which to specialize and realize a human potential. From the ages of ancient Rome to the present, the profession of a lawyer has been respectable and special. This profession is one of the most prestigious specialties which is still popular among prospective students. A profession of a lawyer is alive and the size is subject to change (What is the future of legal education in Latvia.). There is an opinion to be supported that it is not justified to distinguish between professional and academic qualification in law science because basic issues a lawyer-professional and „clean” science are dealing with cannot completely be distinguished too. The labour market requires lawyers with good theoretical knowledge and skill to apply this knowledge in practice. Law science needs scientists who develop the theoretical basis by understanding and taking into account the empirical regularities.

The aim of the article is to identify the current practice of implementation of law science curricula and of study courses by modelling their potential development trends according to perspective social-economic development of society. To achieve the aim set the most important objectives are to describe the role of a lawyer in public processes and to highlight current events of implementation of legal education in Latvia. It is rightly highlighted in the legal literature that any of the most precise and sophisticated means will not provide the expected result if they are put at the disposal of an unprepared person 
(Statkus, 2000).

Legal acts and scientific literature are used in the article. In the development stage of the article the analytical scientific method, as well as the methods for interpreting of legal norms such as grammatical, historical, systemic and theological are used. To draw conclusions there is both inductive and deductive research method used.

\section{Mission of a lawyer for benefits of society}

The term „law science” is equal to the term ,jurisprudence” (from Latin ius, iuris „law”+ prüdentia „wisdom”). Law science or legal science is a branch of science that studies the regulation of public relations by law, as well as the procedures for the execution of rights and the fulfilment of obligations to improve the functioning of the mechanism of state authority and administration, the protection of the economic and social interests of natural and legal persons and to prevent criminal offences and other infringements of rights (Torgāns, 2019).

Law as a regulator of social life determines the pattern of behaviour acceptable to society. The famous US lawyer Roscoe Pound has defined the profession of a lawyer as a pool of educated persons serving for the needs of society. This job is also a source of daily bread. However, the use of knowledge and skills for the interests of society is the main task of the profession (Pound, 1953). Rightly to point out that the ethical conditions of the legal profession should promote the ideals of democracy, justice and the rule of law in society (Kūtris, 2010).

In the course of the development of humanity, rights have been branched into: public law (constitutional, administrative, financial, criminal) and private (civil, labour, commercial, intellectual property, etc.). The Latvian Council of Science has defined seven areas in which doctoral theses, scientific project can be developed, international symposia, conferences, seminars etc. can be organizedcivil law, criminal law, national law, international law, forensics and theory of operational activities, police law, law theory and history.

The impact of globalization is more and more felt in the development of multicultural societies. There is not only a sufficiently free movement of people, goods, capital and services across borders, but also the availability of a single educational area and the use of educational resources. Despite the diversity of national legal frameworks and legal practices, international institutions are seeking to create a single legal environment. Not only universal human and multicultural values are getting increasingly similar and more acceptable in the face of globalization, but also legal norms and the process of their implementation are getting verified. In this respect, the challenge of the globalization of legal education is becoming of importance. Lawyers with a variety of academic 
biographies have to provide increasingly demanding and high-quality legal services and legal assistance in different countries and regions. National legal education models need to include prospective lawyers in a transnational environment.

The qualitative development and application of legal norms is one of the most important aspects that develop public confidence in rights, public administration and the courts. Therefore, it is very important to provide adequate legal education to prepare lawyers who will give the public confidence in the courts (Medina \& Salinieka, 2020). In a flexible response to trends in society Rīga Stradiņš University is developing study courses on human security and safety, conflictology, the use of electronic means of communication and databases. The specialization of RSU Law Faculty is unique, nowhere else in Latvia there are medical and social rights, for which the historical profile of the university medicine - provides the best preconditions for studies. Since academic year 2010/11 RSU has been implementing programmes and curricula that replace the studies of the closed Latvian Police academy. Students are offered to specialize in police law at all the levels of study programmes, including in them forensics, methods of personal enquiry, methods of operational enquiry (RSU Juridiskā fakultāte).

\section{Future of legal education in Latvia}

A profession of a lawyer involves both providing legal assistance to others in protecting their rights and holding positions of national importance (including judges, prosecutors), so it is important that the requirements for obtaining a lawyer qualification are sufficiently high and their enforcement is controlled and monitored (Medina \&Salinieka, 2020). The report of the Ministry of Justice from November 10, 2015, entitled "On introduction of state unified lawyer qualification examination" determined a change of the legal system and a new approach to the quality control in education. One of the prerequisites for the introduction of a unified lawyer qualification examination was the termination of the professional qualification of a lawyer.

On April 20, 2017 the Saeima adopted the amendments to the Law of Higher Education Institutions, which provides that the Cabinet may determine that a part of the state examination in certain second level higher vocational education study programmes is a State exam (Article 58, Paragraph 4, Law of Higher Education Institutions). In accordance with the provisions of the Cabinet Regulations No. 46 of 15 January 2019 "On State Unified Lawyer Professional Qualification Examination Procedure" it is intended to introduce a state unified lawyer qualification examination from the spring semester of 2021. The rules and regulations are designed and implemented with the aim to addressing the 
shortcomings identified when starting work on the state unified lawyer professional qualification examination. The rules and regulations, as well as the annotation added, do not contain a list of shortcomings, which may have been identified in the legal education process, and their analysis. Such shortcomings as in any educational system can be identified. It is essential to recognize that it is objectively difficult to assess whether a state unified lawyer qualification examination will help to achieve a goal, to address undetected gaps, and to improve the quality of legal education. The methodology for determining the quality of legal knowledge and skills could not be linked only to the Cabinet regulations. At the same time, it should be acknowledged that public administration institutions do not have criteria and methods to establish the level of legal knowledge and skills. This applies not only to graduates of law science study programs of higher education institutions, but also to legal practitioners.

The qualification examination should be passed in higher education institutions, which implement professional master's study programme to acquire a lawyer's professional qualification.

Paragraph 24 of these Regulations provides that in the qualification examination the student's knowledge and skills are examined in the following fields:

1. criminal law and criminal procedure law;

2. civil law, civil procedure law and commercial law;

3. constitutional law, administrative law and administrative procedure law;

4. international and European Union law;

5. theory of law, philosophy of law and history of Latvian law.

Paragraph 25 of the Regulations provides that the qualification examination shall be organized in the following parts:

1. the theoretical part, where detailed answers to 15 questions in writing are provided (each of the field referred to in Paragraph 24 of this Regulations contains three questions);

2. Practical part, where five practical tasks (cases) in writing are solved (there is one task (case) in each of the fields referred to in Paragraph 24 of these Regulations).

Among other things, the course and progress of the introduction of the state unified lawyer qualification examination provides that during the spring session of 2020, the University of Latvia shall ensure the possibility of passing an examination in the form of a pilot project.

On the basis of the research materials in Latvia it is concluded that, according to the students' opinion, the most effective form of knowledge acquisition is lectures by lecturers, followed by practical classes, finally - students' owninitiative work and preparation of course papers and reports. Students have 
recognized that participation in scientific conferences the most inefficient form (Mašošins, 2019). On the other hand, cross-border experience shows that studying outside Latvia has its own peculiarities, as there are no lectures, but there are workshops and group work. For example, when comparing the training/education process in Latvia and the US, it is appropriate to mention the socratic method. This method is comparable to workshops in Latvia, but with the difference that it is every lesson. For example, students should read 30-60 pages each time regularly to discuss in the class. US students have the opportunity to help professors write books and articles, as well as there is a number of other extracurricular activities (Kakstāns, 2018). In supporting the view that it is not possible to remain confined in sub-disciplinary fields today. The labour market is still open to professional and knowledgeable lawyers who know not only Latvian, but also international legal norms and regulations. A competent lawyer will always be appreciated in both public authorities and enterprises, and municipal authorities. It should be accepted that education is no longer a material category today, but a form of experience (Teorija pokolenij). Accordingly, it should be pointed out that students should be oriented towards interdisciplinarity.

Continuous professional development and ensuring the lifelong learning and study process of lawyers after the acquisition of bachelor's or master's study programmes is insufficient. Increasing legal professional skills, at best, takes place in a self-taught way that does not ensure the high quality of the necessary knowledge and skills to be acquired. Lifelong or further education in the legal education system in Latvia is not fully provided and an appropriate system is not developed in the country at a level that would correspond to the size of the legal requirements. In Education Development Guideline 2014-2020 it is recognized that there is the need to develop an education system for sustainable development: education that contributes to the ability of each individual to acquire the knowledge, values and skills needed for participation in decision-making on individual or collective actions at local and global level, in order to improve the quality of life at present without creating a threat to the needs of future generations.

Raising legal qualification may include the following interrelated segments: (a) acquisition of new regulatory frameworks and legal practices; (b) the absorption of changes, amendments and additions to the existing legal frameworks; (c) mastering and using of new information technologies and training platforms for continuing education and professional development. It should be acknowledged that around 80 directives and 1200 regulations are approved per year in the European Union.

In the context of legal lifelong learning/studies, so-called clinical legal education plays an interesting role. This type of training is rather specific and is not used sufficiently in legal education system of Latvia. Clinical legal education 
is a methodology for teaching in legal training institutions where students under the management of lecturers and legal practitioners represent the interests of real customers. Clinical legal education helps students to acquire knowledge of law science in practice. At the same time, students actually provide legal aid to the socially unsecured groups of society. This method is binding on the fact that it helps not only a student actively acquire legal knowledge, to address a customer's legal challenges, but also to improve their professional skills, to develop communication skills, to engage creatively in problems and challenges, to discuss and to organize students' work.

\section{Key perspective approaches to improving and developing of legal education system}

Transformation of educational environment. The implementation of these directions is linked to the fact that educational institutions, including faculties of law, must be organizationally and content-oriented in order to facilitate new innovative approaches and exchange of new ideas. One of the aspects is the readiness of the education system to adopt new teaching methods, including the use of simulation tools. One of the possible solutions is the creation of a flexible educational environment, where it will be a place for the beginning of creative activity.

The legal environment and its various forms and situations are dynamic. The standardized approach is not always rational in their perception, problem solving and gaining new knowledge. The educational environment and the acquisition of new knowledge and skills can increasingly be developed not only in educational institutions, but also outside them. One of the examples we have already touched on is the establishment of legal clinics and their functioning. The activities of educational institutions should focus on the development of a comprehensive student's personality. To manage this, it is necessary to set clear aims and objectives, establish the necessary organizational support structures, provide training for teachers in the field of digital technologies, review student evaluation systems. It is doubtless that educational institutions would need to radically review the curricula, focus on transferring deeper theoretical knowledge to students, as well as paying a lot of attention to practice using modern technologies.

New technologies are one of the key elements of the transformation of educational environment. To feel free in the digital world, it is not only enough to have an opportunity to use technology. But the technological and digital opportunities are not enough in the world to be able to use technology, it is important to understand how we can use technology to improve our lives, increase professional capacity and work effectively. Universities need to develop a deeper 
understanding of the digital environment, the ability to adapt intuitively to new conditions and create new content.

The effectiveness of online learning, as well as mobile and blended learning is not a question. Online education is the biggest challenge in higher education. Though universities compete for every student, educational platforms yield millions of students. For example, only Udemy platform offers 100,000 online video courses with new additions and updates being published each month (Udemy).

Online courses allow students to choose what they want and gain knowledge in a short period of time anywhere, at less cost. Online training provides a sense of freedom and control over its development process, which is one of the main drivers of obtaining the desired result. The presence of such advanced technological solutions, for example, online education, blended and mobile learning at the university, is a key factor of the success of legal education. At the same time, it is necessary to monitor and control the impact of education technologies on learning outcomes.

The development of modern law science and its inclusion in a legal education system not only determines the use of forms, new technologies, but also the creation of innovative study courses and the development of their content. Such study courses as Legal programming, the Rights of technologies, E-commerce legal regulations, the Digital environment legal framework, Digital litigation (digital process), Human Rights in the digital environment, etc. should be included in the new legal professional standard. For example, Harvard university offers a sufficiently extensive courses of innovative studies, including specialized computer science courses for lawyers (Harvard University).

Using technical instructions and discussions about case studies, this course gives students the opportunity to be informed about technology-driven processes. The course enables students to formulate legal arguments and opinions based on technologies. In parallel, it provides students with practical experience with Python and SQL-languages that give them data to get answers. Topics of the course include the development of algorithms, cloud computing, databases, networking, privacy, programming, security, and many others, with particular emphasis on how developers and the technological solutions they use work that can affect customers. This course at Harvard University is an introduction to computer science. This course is also implemented online as a series of video modules that can be accessed by your own schedule. No prior programming experience is required (The Learning Model).

The development and application of methodologies for the assessment of skills in processes at individual level are essential. Educational institutions must change by increasing their flexibility in line with labour market requirements. Individualization of education is an integral part of this process. The first step is 
to create a personalized evaluation of learning outcomes. This gives a clearer picture of what students need to know to acquire certain skills and competencies. The most demanding future skills will be students' professional, creative and critical thinking skills. The priority of higher education institutions is the development of criteria for assessing such skills.

At present, there is already a number of successful projects in the world practice in the field of assessment of skills at individual level.

It must be acknowledged that in the context of globalization cooperation is as one of the key factors in ensuring effective solutions, including the field of legal education. One of the main features of modern universities is their ability to cooperate on the world market. The massiveness of higher education and a customer-oriented character led to serious competition between universities, and the globalization of education became the basis for building strategic alliances among several universities from different countries. It is becoming increasingly possible to identify the development of cooperation between education institutions by creating alliances that help to gain favourable positions in the global market for education services.

International cooperation and internationalisation of study processes play an important role in the legal education system, including the context of global law. Such an approach provides opportunities to learn and use the experience of other countries in this field of education, to jointly carry out global theoretical or practical applied researches or to develop projects of public interest, to significantly enrich the organizational, informative, methodological and technological basis of the study process etc. Internationalisation within the legal education system is multi-faceted and includes: mobility and flexibility of the education system, which involves the exchange of students and teachers within international programs; adjusting the standards of legal education in line with the dynamics of socio-economic and political processes and with the standards of legal qualifications in the European Union; regular consultation on methods of teaching in other countries, methodological and study materials; exploring possibilities for their use in Latvian legal education institutions (faculties); involvement of leading researchers and lecturers from other countries in the legal education system and its improvement; development of joint scientific projects and organisation of international symposia, conferences and seminars, etc.

\section{Conclusions}

1. The legal education system, its content, forms, methods and technologies, to some extent, lags behind the dynamism and mobility of socio-political and economic processes. 
2. A profession of a lawyer, as a socially important mission, without changing its spirit and substance is gaining a new content of the dominance of values of justice and democracy in today's world.

3. In times of globalization, despite the diversity of national legal frameworks and legal practices, a single transnational legal environment and a common legal education system are objectively being formed.

4. In order to ensure higher quality of legal education, a state unified lawyer qualification examination, which does not yet provide an unambiguous answer or the professional quality of lawyers will indeed increase as a result of the implementation of examination mentioned, has been introduced in Latvia.

5. Not only the provision of basic education (Bachelor, Master, PhD programmes) is important in the legal education system, but also the further education and professional development and lifelong learning of lawyers.

6. A high-quality legal education system is linked to the development of the necessary material basis, as well as the provision of highly qualified teaching staff, development of a study environment.

7. The use of new technologies, the simulation-based learning process, the wider use of technological platforms, is becoming increasingly important in the legal education system.

8. The development of modern law science and its incorporation into the legal education system requires not only the use of new technologies, but also the development of innovative study courses and their content (eg legal programming, robotics law, digital legal framework, etc.).

9. The involvement of Latvian legal scholars in the Association of European Law Faculties, which includes the involvement of lecturers and students in international legal research, and the continuous updating of legal study materials in the studies, should be encouraged.

10. The authors believe that today's current need is providing maximal activity of students in lessons, dictated by legal practice and an up-to-date procedure of acquiring the study courses.

\section{References}

Augstskolu likums. (1995). Latvijas likums. Latvijas Vēstnesis, 179, 17.11.1995. Pieejams https://likumi.lv/

Gailīte, D. (2019). Simts svecītes uz Juridiskās fakultātes jubilejas kūkas. Jurista Vārds, 22.10.2019., 42(1100), 6-8.

Harward University. Retrieved from https://online-learning.harvard.edu/course/cs50lawyers?delta $=0$

Mašošins, J. (2019). Interaktivitātes metodes juridisko zinātñu studiju kriminālciklā. Sabiedrība un kultūra. Rakstu krājums, XXI, 232-235). 
Proceedings of the International Scientific Conference. Volume II, May $22^{\text {th }}-23^{\text {th }}$, 2020. 414-424

Medina, I., \& Salinieka, I. (2020). Juridiskā izglītības kvalitāte. Kurp ejam? Jurista vārds, 07.01.2020., 01(1111), 40-43.

Ministru kabineta 2019. gada 15. janvāra noteikumi Nr. 46 "Valsts vienotā jurista profesionālās kvalifikācijas eksāmena kārtība” Pieejams https://likumi.lv/

Kakstāns, Ā. (2018). Juridiskās izglītības tradīcijas Latvijā vēl tikai veidojas. Jurista Vārds, 03.07.2018., 27(1033), 6-9.

Kūtris, G. (2010). Jurista īpašais pienākums pret valsti. Jurista vārds, 19.01.2010., 3(598), 10-13.

Pound, R. (1953). The Lawyer from Antiquity to Modern Times: With Particular Reference to the Development of Bar Associations in the United States. St. Paul: West Publishing Company.

RSU Juridiskā fakultāte. Pieejams https://www.rsu.lv/juridiska-fakultate

Statkus, V. (2000). Nekotorye problemy podgotovki specialistov po raskrytiju i rassledovaniju prestuplenij. Vestnik kriminalistiki.1, 35-41.

Teorija pokolenij. Retrieved from http://www.marketing.spb.ru/lib-around/socio/ generation.htm

The Learning Model. Retrieved from https://online-learning.harvard.edu/course/computerscience-lawyers?delta $=0$

Torgāns, K. (2019). Tiesību zinātne Latvijā. Pieejams https://enciklopedija.lv/skirklis/9933tiesību-zinātne-Latvijā

Udemy. Retrieved from https://www.udemy.com/ 